\title{
The Sixth Battalion, On Guard! (Šiesty prápor, na stráž!)
}

\author{
Author: Emil F. Knieža
}

First Published: 1964

Translations: Czech (Košer rota, 1966); German (Jankel Tannenbaums Kompanie, 1975); in part English (Chapter XII To Eat or Not to Eat? In: An Anthology of Slovak Literature, 1976, pp. 297-304).

About the Author: Emil F. Knieža's (1920-1990) original name was Emil Fürst (the German Fürst means Knieža in Slovak). He came from a Slovak-Jewish family in Eastern Slovakia (Nacina Ves near Michalovce). During World War II, he was forced to serve in the 6th Battalion of the Slovak Army, in the so-called "labour company" (see also Leopold Lahola). From 1943 he fought in the Jegorov Partisan Brigade against the Nazis. After his graduation from high school in Bratislava (1945), he worked as a journalist in daily newspapers and as an editor in a publishing house. Later he was the director of the Municipal Library in Bratislava. His first short stories were published in 1957. In 1962, he became a professional writer. After the Soviet invasion of Czechoslovakia in August, 1968, Knieža emigrated to Switzerland where he lived in Benglen and worked in a bookstore.

Knieža published articles about Jewish culture, antisemitism and Zionism in Slovak as well as in other languages. He translated two of Sholem Aleichem's literary works, Tevye, the Dairyman and his Daughters (1959) and Wandering Stars (1962, in cooperation of Marta Ličková) from Yiddish into Slovak.

Further Important Publications: Mušketieri žltej hviezdy (Musketeers with the Yellow Star, 1967; novel); Zvalte všetko na mňa (Blame Everything on Me, 1976; novel).

\section{Content and Interpretation}

The novel is divided into 37 chapters. It is set in Slovakia from March of 1941 to June of 1943. The phrase “On guard!” („Na stráž!“) in its title was a military salute of the Slovak Army and Hlinka Guard (the Slovak Fascist organisation) during World War II. Paradoxically, it was also the salute of the Jewish "labour squads" that were a part of the army. Their members were Slovak Jews, taken away into military service, but without being armed with weapons.

The main characters are three young men from the small village Suchá-Dlhá near Michalovce in East Slovakia: Jankel (Jacob) Tanenbaum, Josel (Joseph) Hopkovič and Mikolaj Gerebla. Jankel and Josel are Jews and are included in the "kosher company" for Orthodox Jews, Mikolaj as a Slovak in the "Aryan company" in the same battalion. They serve and labour first in Eastern Slovakia and later in Western Slovakia. 
There are different kinds of individuals in Jewish companies. Poor Orthodox Jews from Eastern Slovakia, speaking Yiddish and the Slovak Zemplín dialect (Jankel Tanenbaum). Then liberal and assimilated Jews from Bratislava, speaking German and Hungarian (Walter Kahan). Finally they are communists (Šaňo Schön) and Zionists ("Barcelona” Suchý) there. Often they don't understand each other. Their Slovak commanders are usually incompetent and the Jewish soldiers make a mockery of them. Jews also meet German units getting ready for the invasion of Russia and the Jews scoff at them:

\footnotetext{
"You're splendid fellows! It's go swimmingly! You're taking land by land if on a walk".

"Now London and Moscow, and it will be the end", the German gave a faint smile.

"And something else", added Grün, "M’pole".

"We'll take it too, cha cha", said the German and everybody laughed with taste at the rebbes joke. (Knieža, 1964, p. 100) [“M’pole” means destruction, plague.]
}

Nevertheless, the situation of the Jews in Slovakia step by step becomes more complicated. Officers' behaviour towards Jewish soldiers becomes tougher, mainly after the "Jewish Codex" in Slovakia is declared (September, 1941) that restricts the rights of the Jews substantially. In March, 1942 transports of Slovak Jews to labour camps and to death camps begin. Many relatives, friends or girlfriends of Jewish soldiers are deported and they themselves are also in danger. Jankel gradually loses his faith in the omnipotence of God. His friend Josel asks “Where is God?” and Jankel can't answer (p. 280). This motif often appears in Holocaust literature, see $\rightarrow$ Court Jesters (Viktor Fischl), $\rightarrow$ A Private Conversation (Hana Bořkovcová) or $\rightarrow$ It Happened on the First September (Pavol Rankov). He looks for hope in the idea of communism but is also not completely satisfied with it.

Some of the Jewish soldiers try to run away and desert, joining partisans in the mountains, some of them save themself with "Aryan papers" (Šlojme Mendlovič) or flee to Hungary. Heinz Schaler commits suicide. Walter Kahan joins voluntarily his family in the transport to the camps.

The fate of Slovak soldiers is also tragicomic. Mikolaj Gerebla reports for the Eastern front as a volunteer, to have cigarettes and an additional payment of 10 crowns daily. He experiences rough situations there, such as the mass killing of the Jews in Ukraine. He meets Timotej Pukanič, the former commander of the "Jewish company" there. Pukanič is a primitive alcoholic and hoarder who is finally sent to a madhouse at last. (However, he appears in Slovakia again, in the second and third parts of the trilogy.)

The Slovak society is divided in relation to the persecution of the Jews. Government officials and Hlinka Guards support the deportation of the Jews mainly to take possession of their Jewish property. On the other hand, many Slovaks help the Jews. So the villagers in Suchá-Dlhá stand up for the Jews when the authorities confiscate their cows and goats. The local Orthodox Catholic priest Fedorčák baptises Jews to save them. He is arrested but the villagers protest against it. 
The illegal Jewish “Working Group” in Bratislava, led by Irena Altmannová, tries to rescue the remaining Jews in Slovakia. They bribe the Slovakian government officials and the German official responsible for the "Final Solution" in Slovakia Vysletschenski, using money from foreign Jewish organisations. Transports are stopped and everyone believes they will not be continued.

At the end of the novel, in June, 1943, the Sixth Battalion is disbanded. Most of the Jewish soldiers disappear.

\section{Main Topics and Problems}

The novel exploits various narrative devices: the personal perspectives of characters, dialogues but also author's comments, and “documents" (reports from newspapers and decrees as well as fictive letters). Many Yiddish or Hebrew words are used in dialogues or reflections of characters, for instance "chóchem”, "chochmes” (wise, wisdom), "Jeke” (Germans or German speaking Jews) and liturgic terms: “dajen” (reeve, judge). Also the East-Slovak Zemplin dialect is often exploited. A glossary of these terms is added at the end of the book.

News from the official newspapers and decrees present the ritual ideological jargon. Tiso, the Slovak President, declares war against the Soviet Union as a "crusade against the Jewish-Bolshevik plague" (p. 154). A comic effect often arises due to the contrast between the Slovak governments' official narrative and documents included the letters and statements of direct witnesses.

Some of the characters, mentioned in the novel, are authentic: for instance the mentioned Tiso or the Prime Minister Vojtech Tuka. Other characters allude to obviously real people, like the Interior Minister Aladár Mak (Alexander Mach), the editor-in-chief of the newspaper Belo Durman (Milo Urban), the leader of the Bratislava Working Group which rescued Jews Irena Altmannová (Gisi Fleischmannová), the German official responsible for the "Final Solution" in Slovakia Vysletschenski (Dieter Wisliceny), the Slovak general Tichomír Čontoš (Ferdinand Čatloš) etc. Also the main plot, Jewish companies in the Slovak Army (men born in 1920 and 1921), is authentic. The author knew these units from his own experience.

The novel The Sixth Battalion, On Guard! is the first volume of the trilogy. In 1967 follows the novel Musketeers with the Yellow Star that narrates the fate of the main characters and other figures in the last years of World War II (1943-1945). Their postwar life in the Communist society until the Soviet invasion in the August, 1968 is described in the novel Blame Everything on Me (1976) edited in the exiled publishing house Polana in Zürich. All these novels use the same narration and composition combining "documents" and "fiction", authentic and fictive characters. Nevertheless, in the second and third parts of the trilogy, the story breaks down into a series of free episodes.

Comic and grotesque scenes in the novel can be inspired by Jewish humour, for instance the works of Sholem Aleichem that the author translated. To some extent, these scenes are close to the another Slovak Jewish writer Ladislav Grosman $(\rightarrow$ The 
Shop on Main Street). Another source of inspiration can be Jaroslav Hašek and his novel The Good Soldier Švejk from World War I. Jankel is a figure similar to Švejk, the villain Badinský hints at Biegler in this novel, Pukanič at dull Austrian officers etc.

\section{Cited Works}

Knieža, E. F. (1964). Šiesty prápor, na stráž! Bratislava: Vydavatel’stvo politickej literatúry. Knieža, E. F. (1965). Bojová kapitola slovenských Židov. Židovská ročenka, 5725, pp. 134-140.

\section{Further References}

Grébert, A. (1975). Spisovatel’ E. F. Knieža. Horizont, 3(11), p. 8. Hek, J. (1966). Emil F. Knieža: Košer rota. Impuls, 1(7), pp. 515-516. Chorvát, M. (1964). Nová téma - nové márnosti. Kultúrny život, 19(27), Knězek, L. (1990). Zomrel Emil Knieža. Literárny týždenník, 3(37), p. 2. Knězek, L. (1994). Knieža, Emil F. (pôvodným menom Fürst). Romboid, 29(3), pp. 39-40. Nižňanský, E., Baka, I, Kamenec, I., eds. (2004). Holokaust na Slovensku 5: Židovské pracovné tábory a strediská na Slovensku 1938-1944. Dokumenty. Zvolen: Klemo.

$\mathrm{JH}$ 